Arab World English Journal (AWEJ) Special Issue on CALL Number 4. July 2018

DOI: https://dx.doi.org/10.24093/awej/call4.3

Pp.24- 39

\title{
An Analysis of Learner Autonomy and Autonomous Learning Practices in Massive Open Online Language Courses
}

\author{
Hülya Mısır \\ Department of English Language Teaching \\ Faculty of Education, Ufuk University, Ankara, Turkey \\ Didem Koban Koç \\ Department of English Language Teaching, \\ Faculty of Education, Hacettepe University, Ankara, Turkey \\ Serdar Engin Koç \\ Department of Computer Education and Instructional Technologies \\ Faculty of Education, Başkent University, Ankara, Turkey
}

\begin{abstract}
The study investigates the perception of learner autonomy with Massive Open Online Language Course (MOOLC) participants, more specifically; (i) to what extent EFL learners in an English MOOLC are autonomous, (ii) the perception of learners' and teachers' roles in learner autonomy, and (iii) the autonomous learning practices the learners are involved in by participating in the MOOLCs. It contributes to the understanding of online learner as an agent in highly heterogeneous language learning contexts and the link between online learning and learner autonomy. The mixedmethod design is employed to present data from a Learner Autonomy Questionnaire by Joshi (2011) conducted with 57 participants from three English MOOLCs with a variety of focus as well as a content analysis method was used on the interaction data in the form of open discussion forum posts, which were added by the participants, to create a frame of autonomous learning activities in these MOOLCs and learners' attitudes towards them. The findings show that the English MOOLC participants are highly autonomous and willing to be more responsible for their own learning. Similarly, the learners' perception of their own roles indicates a positive inclination towards autonomy. Furthermore, the participants favor the MOOLCs that encourage learner-centered and autonomous language learning practices. Due to the interactive, communicative, and collaborative nature of MOOLCs, learners are advised to develop globalized autonomous skills to participate effectively in such multicultural learning platforms because learner autonomy goes beyond traditional classrooms.
\end{abstract}

Keywords: Connectivist theory, English as a foreign language, language MOOCs, learner autonomy, massive open online language courses

Cite as: Misır, H., Koban Koç, D., \& Koç, S.E. (2018). An Analysis of Learner Autonomy and Autonomous Learning Practices in Massive Open Online Language Courses. Arab World English Journal (AWEJ) Special Issue on CALL (4) DOI: https://dx.doi.org/10.24093/awej/call4.3 